\title{
POLYOXOMETALATES FOR RADIOACTIVE WASTE TREATMENT
}

\author{
Annual Report \\ Grant No: DE-FG07-96ER14695
}

Period of Report: 06/15/96 - 09/30/97.

Principal Investigator: Michael T. Pope, Professor

Department of Chemistry, Georgetown University, Washington DC 20057

Four areas of research have been investigated during the first year of this project:

$\begin{array}{ll}\text { - } & \text { Selective separations of } \mathrm{Ln}^{3+} \text { and } \mathrm{An}^{4+} \\ \text { - } & \text { Very large tungstate complexes of } \mathrm{Ln}^{3+} \\ \text { - } & \mathrm{U}^{4+} \text { and } \mathrm{UO}_{2}^{2+} \text { polytungstate complexes } \\ & \text { Rhenium (technetium) polyoxometalates }\end{array}$

Progress in each of these areas is summarized below

\section{Selective Separation of $\mathrm{Ln}^{3+}$ using $\left[\mathrm{NaP}_{5} \mathrm{~W}_{30} \mathrm{O}_{110}\right]^{14}(\mathrm{I})$}

In previous work we had shown that the central sodium cation in the doughnut-shaped heteropolytungstate $\left[\mathrm{NaP}_{5} \mathrm{~W}_{30} \mathrm{O}_{110}\right]^{14-}$ (I) could be replaced by cations of similar size $\left(\mathrm{Ln}^{3+}, \mathrm{An}^{4+}\right)$ under hydrothermal conditions (aqueous solution, $150-180^{\circ} \mathrm{C}, 10-40 \mathrm{~h}$ ). [-Rigid Non-Labile Polyoxometalate Cryptates $\left[\mathrm{ZP}_{5} \mathrm{~W}_{30} \mathrm{O}_{110}\right]^{(15-n)-}$ that Exhibit Unprecedented Selectivity for Certain Lanthanide and Other Multivalent Catiol Creaser, I.; Heckel, M.; Neitz, R.J.; Pope M.T.,Inorg. Chem., 1993, 32, 15731578.] We have examined the parameters of this process more closely, and through the use of competitive experiments have shown that although all Ln cations can undergo exchange the

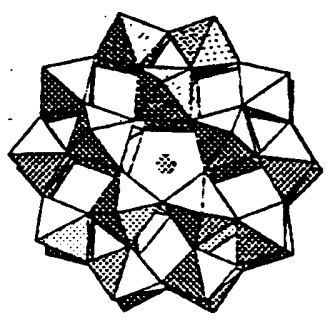
optimum size corresponds to those near the middle of the lanthanide series, e.g. Eu. Other cations which often are the predominant species in tank wastes $\left(\mathrm{Fe}^{+}, \mathrm{Al}^{3+}\right)$ are completely excluded from binding to I. Thanks to their higher charge the lanthanide cations compete very favorably with $\mathrm{Na}^{+}$which is the major species present.

"The Structures of Europium(III)- and Uranium( IV) Derivatives of $\left[\mathrm{P}_{5} \mathrm{~W}_{30} \mathrm{O}_{110}\right]^{15}$. Evidence for Cryptohydration", Dickman, M.H.; Gama, G.J.; Kim, K.-C.; Pope, M.T., J. Cluster Sci., 1996, 7, 567-583

Kim, Kee-Chan; Pope, M.T. In preparation 


\section{Very Large Tungstate Complexes of the Lanthanides}

By focussing on the binding of $\mathrm{Ln}^{3+}$ (as a component of radioactive waste and as a stereochemical surrogate for $\mathrm{An}^{4+}$ ) into polytungstates, we have uncovered a group of large (indeed, extremely large) heteropolyanions. Although in most cases these are formed by "self-assembly" from their constituent atoms, their structures reveal a common building block, $\left[\mathrm{As}^{\mathrm{W}} \mathrm{W}_{9} \mathrm{O}_{33}\right]^{9}$. The latter may be viewed as a lacunary derivative of the Keggin structure. The three new complexes, illustrated below, include an unprecedentedly massive anion with 164 metal atoms.

$$
\begin{aligned}
& {\left[\mathrm{As}_{3} \mathrm{Ln}_{2} \mathrm{~W}_{29} \mathrm{O}_{103}\left(\mathrm{H}_{2} \mathrm{O}\right)_{7}\right]^{17-} \text { or }\left[\mathrm{Ln}_{2}\left(\mathrm{H}_{2} \mathrm{O}\right)_{7}\left(\mathrm{AsW}_{9} \mathrm{O}_{33}\right)_{3}\left(\mathrm{WO}_{2}\right)_{2}\right]^{17-} \text { (II) }} \\
& {\left[\mathrm{Ce}_{4}\left(\mathrm{AsW}_{9} \mathrm{O}_{33}\right)_{4}\left(\mathrm{WO}_{3}\right)_{3} \mathrm{WO}_{5}\right]^{28-}(\mathrm{III})} \\
& {\left[\mathrm{As}_{12} \mathrm{Ce}_{16}\left(\mathrm{H}_{2} \mathrm{O}\right)_{36} \mathrm{~W}_{148} \mathrm{O}_{524}\right]^{76-} \text { (IV) }}
\end{aligned}
$$

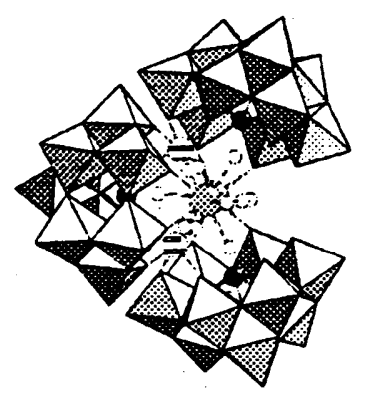

II

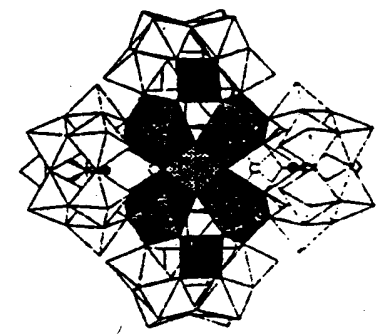

III

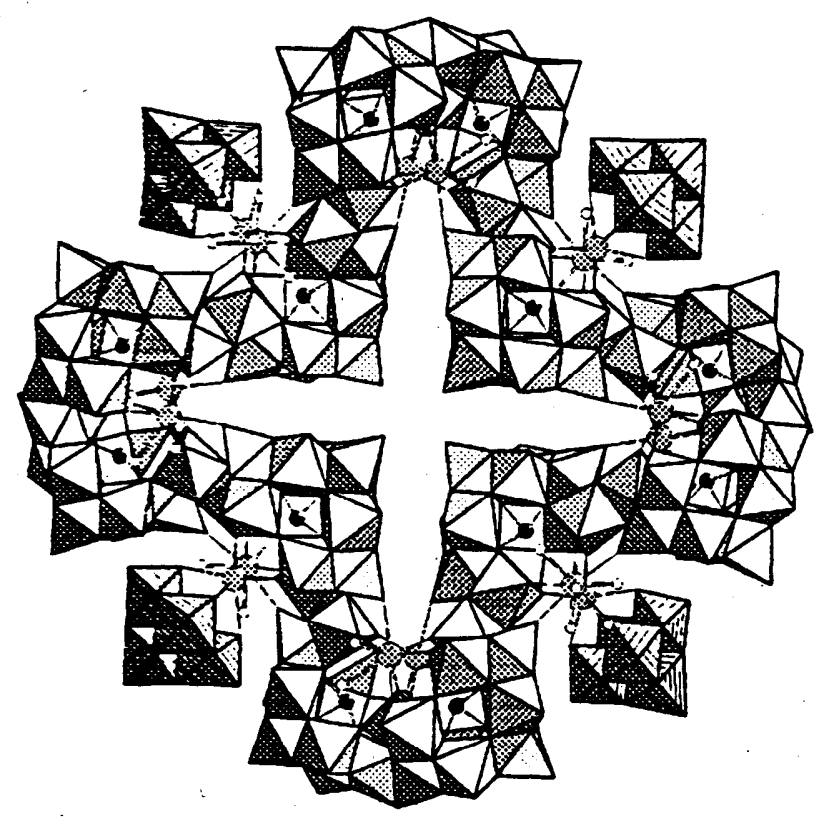

IV 
Anion IV is formed in good yield and is stable in aqueous solution at neutral $\mathrm{pH}$. The structure has virtual $D_{2 \mathrm{~d}}$ symmetry and this is confirmed in solution via the ${ }^{180} \mathrm{~W}-\mathrm{NMR}$ spectra of the $\mathrm{Ce}^{\mathrm{III}}$ and $\mathrm{La}^{\mathrm{m}}$ derivatives.

"Self-Assembly of Supramolecular Polyoxometalates. The Compact, Water-Soluble Heteropolytungstate Anion $\left[\mathrm{As}^{\mathrm{a}}{ }_{12} \mathrm{Ce}^{\mathrm{m}}{ }_{16}\left(\mathrm{H}_{2} \mathrm{O}\right)_{36} \mathrm{~W}_{148} \mathrm{O}_{524}\right]^{76-1 ",}$ Wassermann, K.; Dickman, M.H.; Pope, M.T., Angew.Chem., 1997, 109, 1513-1516;

Angew. Chem. Internat. Ed. Engl., 1997, 36, 1445-1448

"New Developments in the Chemistry of Heteropolytungstates of Rhodium and Cerium" Pope, M.T.; Wei, X.; Wassermann, K.; Dickman, M.H., Bull.Soc.Chim.France submitted for publication.

Preliminary experiments have been carried out on the thermal decomposition of ammonium salts of anions II - IV. Following loss of crystal water and ammonia, all three salts exhibit sharp exotherms at $\sim 550$ and $\sim 600^{\circ} \mathrm{C}$. X-ray powder investigation of the product of IV heated to $560^{\circ} \mathrm{C}$ showed the formation of the hexagonal tungsten bronze (reduction caused by the ammonia released). This is an encouraging observation in connection with the proposed generation of tungsten bronzes for inert storage of lanthanide/actinide cations. Future investigations will examine the effects of hydrogen reduction of these and similar materials.

\section{Polytungstate Complexes of Uranium}

Uranium(IV) tungstate complexes have been known for about 20 years and we have reexamined some of these with respect to their structures and stabilities. Typical compositions of these complexes are exemplified by $\left[\mathrm{U}\left(\mathrm{SiW}_{11} \mathrm{O}_{39}\right)_{2}\right]^{12-}(\mathrm{V})$ and $\left[\mathrm{U}\left(\mathrm{a}_{2}-\mathrm{P}_{2} \mathrm{~W}_{17} \mathrm{O}_{61}\right)_{2}\right]^{16-}(\mathrm{VI})$. In addition to structural analyses of $\mathrm{V}$ and $\mathrm{VI}$ we have also synthesized mixed-ligand complexes involving $a$, and $\alpha_{2}$ isomers of $\left[P_{2} W_{17} O_{61}\right]^{10-}$. The former $\left(\alpha_{1}\right)$ species is chiral, and an elaborate system of diastereomers of the uranium complexes has been uncovered and examined by P-NMR spectroscopy and X-ray structure determination.
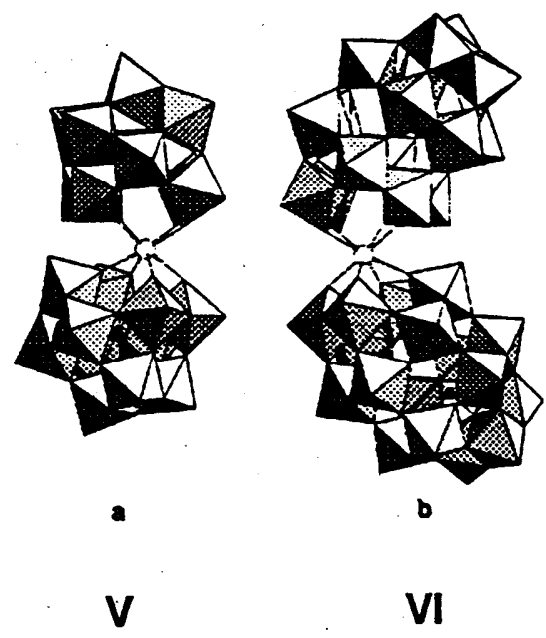

VI

Kim, Kee-Chan; Pope, M.T. In preparation

Ostuni, A.;. Bachman, R.; Pope, M.T. In preparation 
Although the $U^{N}$ derivatives like $\mathbf{V I}$ are hydrolytically stable in neutral and sightly basic media, the uranium in tank wastes is likely to involve oxidized $\left(\mathrm{UO}_{2}{ }^{2+}\right)$ species. No heteropoly-tungstates incorporating uranyl hetero groups have been reported to date, but there seems to be no inherent reason why such species should not be accessible. We have therefore investigated the interaction of $\mathrm{UO}_{2}{ }^{2+}$ with lacunary polytungstate anions that are stable in neutral or basic solution. With $\left[\mathrm{As}^{\mathrm{II}} \mathrm{W}_{9} \mathrm{O}_{33}\right]^{9-}$, a "trimeric" species is formed, $\left[\left(\mathrm{UO}_{2}\right)_{3}\left(\mathrm{~W}_{2} \mathrm{O}_{5}\right)\left(\mathrm{H}_{2} \mathrm{O}\right)_{5}\left(\mathrm{AsW}_{9} \mathrm{O}_{33}\right)_{3}\right]^{19-}$ (VII) of virtual $\mathrm{C}_{5}$ symmetry. The new anion is itself a lacunary species and appears to bind additional "octahedral" cations, e.g. $\mathrm{Mn}^{2+}, \mathrm{VO}^{2+}$.

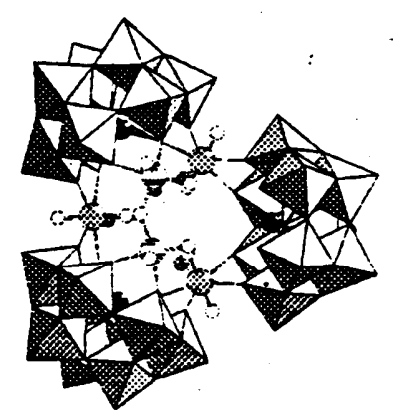

VII

Complexes of $\mathrm{UO}_{2}{ }^{2+}$ with A-type $\left[\mathrm{PW}_{9} \mathrm{O}_{34}\right]^{9-}$ have 2:2 stoichiometry, and display unprecedented cation-dependent isomerism. In the presence of sodium cations, $\left[\mathrm{Na}_{2}\left(\mathrm{UO}_{2}\right)_{2}\left(\mathrm{PW}_{\mathrm{g}} \mathrm{O},\right)_{2}\right]^{12} \sim\left(\mathrm{VIII}, \mathrm{C}_{2 \mathrm{n}}\right.$ symmetry), is formed, but the addition of $\mathrm{K}^{+}$or $\mathrm{NH}_{4}^{+}$ leads to the gradual formation of $\left[\mathrm{M}_{2}\left(\mathrm{UO}_{2}\right)_{2}\left(\mathrm{PW}_{9} \mathrm{O}_{34}\right)_{2}\right]^{12-}(\mathrm{IX}, \mathrm{C}$ s symmetry).

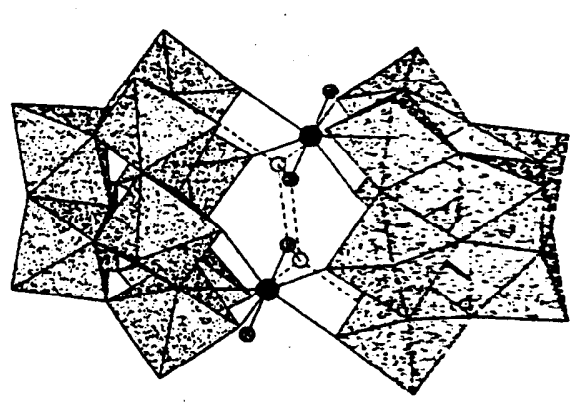

VIII

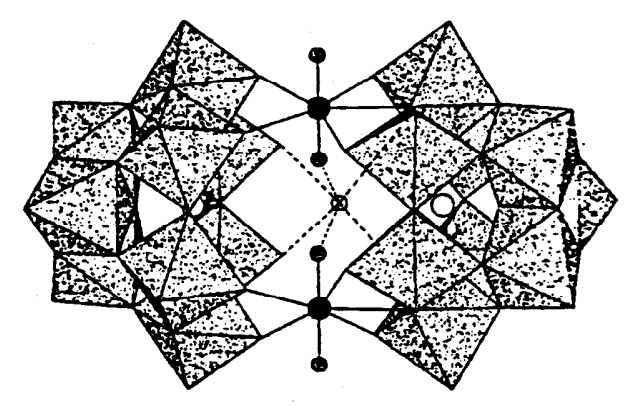

IX

The equilibrium

$$
\mathrm{VIII}+2 \mathrm{M}^{+}=\mathrm{IX}+2 \mathrm{Na}^{+}
$$


can be followed by P-NMR, $\mathrm{K}=140 \pm 20\left(\mathrm{M}=\mathrm{K}^{+}\right)$and $2.0 \pm 0.7\left(\mathrm{M}=\mathrm{NH}_{4}{ }^{+}\right)$

The analog of anion VIII with [ $\left.\mathrm{SiW}_{9} \mathrm{O}_{34}\right]^{10-}$ has also been prepared and structurally characterized.

Kim, Kee-Chan; Pope, M.T., In preparation

\section{Heteropoly Complexes of Rhenium (Technetium)}

This part of the research program has only just been initiated (A. Besserguenev). Preliminary results indicate that $\mathrm{Re}^{\mathrm{iv}}$ complexes of molybdates and tungstates with the "Anderson" structure, $\left[\operatorname{Re} \mathrm{M}_{6} \mathrm{O}_{24}\right]^{8-}(\mathrm{M}=\mathrm{Mo}, \mathrm{W})$, might be formed. The interaction of $\mathrm{Rel}^{v}$ and $\mathrm{Re}^{v}$ complexes with various lacunary polytungstates is also in progress.

This part of the research project is directed ultimately towards the binding and separation of technetium analogues of appropriate rhenium species.

\section{Personnel}

Michael T. Pope, Principal Investigator

Knut Wassermann, Postdoctoral (with partial support from DAAD)

Michel H. Dickman, Postdoctoral (part time)

Kee-Chan Kim, Ph.D. student (3rd year)

Alexei Besserguenev, Ph.D. student (1st year)

Angelo Ostuni, M.S. student

\section{Meeting Presentation}

Pope, M.T at French-German-Polish Symposium on "Recent Progress in Polyoxometalate Chemistry, Paris, 21-22 November, 1996. ["New Developments in the Chemistry of Heteropolytungstates of Rhodium and Cerium" Pope, M.T.; Wei, X..;

Wassermann, K.; Dickman, M.H.] 